\title{
STUDIES OF THE EFFECTS OF LARGE DOSES OF BACTERIAL PYROGEN IN THE DOG. I. THE RENAL HANDLING OF SALT AND WATER ${ }^{1,2}$
}

\author{
BY J. LEONARD BRANDT, BARNETT ZUMOFF, ${ }^{3}$ LEONARD CASTLEMAN, \\ HERMAN D. RUSKIN, AUDREY JONES, AND SEYMOUR ZUCKERMAN \\ WITH THE TECHNICAL ASSISTANCE OF MARY BIANCHI
} (From the Department of Medicine, State University of New York, College of Medicine at New
York City, Brooklyn, N.Y.)

(Submitted for publication March 20, 1956; accepted May 31, 1956)

The augmenting effect of pyrogens on urine flow in the dog has been demonstrated and shown to be associated with increased solute excretion (1) and unresponsiveness of the renal tubule to antidiuretic doses of Pitressin (2). The possible experimental and clinical usefulness of a group of substances which are able to increase solute excretion and interfere with antidiuretic activity is obvious.

The present report records our observations of the renal effects of pyrogen on mongrel dogs and an analysis of the mechanism of a pyrogen diuresis.

\section{MATERIAL AND METHODS}

A total of 21 female mongrel dogs were used in these experiments. All animals were studied in the postabsorptive state under light anesthesia. Initial anesthesia was produced by the intravenous injection of $25 \mathrm{mgm}$. Pentobarbital per kilogram of body weight approximately 45 minutes before the start of any experiment. Light anesthesia was maintained throughout the remainder of the experiment by the administration of $25-\mathrm{mgm}$. doses of Pentobarbital at approximately hourly intervals.

The constant infusion technique was used for the measurement of renal dynamics. Clearances of creatinine $\left(\mathrm{C}_{\mathrm{Cr}}\right)$ and para-aminohippurate $\left(\mathrm{C}_{\mathbf{P A B}}\right)$ were used as measures of glomerular filtration rate and renal plasma flow, respectively. Timed urine collections were made through an indwelling bladder catheter. Mid-period blood sampling was done through a polyethylene catheter from either the femoral or iliac vein. Plasma and urine osmolarity and urine flow were measured, and from these total solute excretion, free water clearance, and osmolar clearance were calculated. Timed urine collections were

1 This work was supported by a grant from the Orange County Heart Association and the American Heart Association.

2 A portion of this work was presented at the Seventh Annual Conference on the Nephrotic Syndrome, Boston, October 22, 1955.

3 Present address: Sloan-Kettering Institute, New York. made for at least 45 minutes before and for more than two hours following the intravenous injection of pyrogen in all experiments. 4

Creatinine concentrations in plasma and urine were determined by the Jaffé reaction (3) ; PAH concentrations in plasma and urine by the method of Smith, Finkelstein, Aliminosa, Crawford, and Graber (4); glucose concentrations by the method of Nelson (5); and chlorides by the method of Schales and Schales (6). Sodium and potassium concentrations were measured with a flame photometer using a lithium internal standard. For the determination of plasma and urine osmolarity, freezing point depressions were measured by means of a Fiske Osmometer.

The animals were divided into four groups as follows:

Group I-six dogs allowed water freely before starting the study received 30 to 50 micrograms of pyrogen 5 intravenously after a set of control periods. The sustaining infusion of test materials was made up in physiological saline, and administered at the constant rate of $2.0 \mathrm{cc}$. per minute.

Group II-six dogs in which tubular maxima for glucose (three dogs) and $\mathrm{PAH}$ (three dogs) were measured before and after a 30 to 50 -microgram dose of pyrogen was given intravenously. The usual procedures for Tm measurements were used (7).

Group III-five dogs in which a constant intravenous water ( 5 per cent glucose in water at a rate of $6 \mathrm{cc}$. per minute) load was given throughout the experiment. After water diuresis was established, Pitressinit in antidiuretic doses was added to the constant infusion (25 to 50 mUnits Pitressin per hour). After antidiuresis had been produced, the dogs received 30 to 50 micrograms of pyrogen intravenously.

Group IV-four hydropenic dogs were given large solute loads (25 per cent mannitol or 12 per cent sodium sulfate) before and after a 30 to 50-microgram dose of

4 The appearance of what is subsequently termed "pyrogen effect" was determined by the sudden rise in urine flow during each experiment.

5 The pyrogen used in this study was Piromen, a polysaccharide derived from the Pseudomonas aeroginosa. The material was supplied by Travenol Laboratories, Morton Grove, Ill., and contains ten micrograms of pyrogen per cc. 

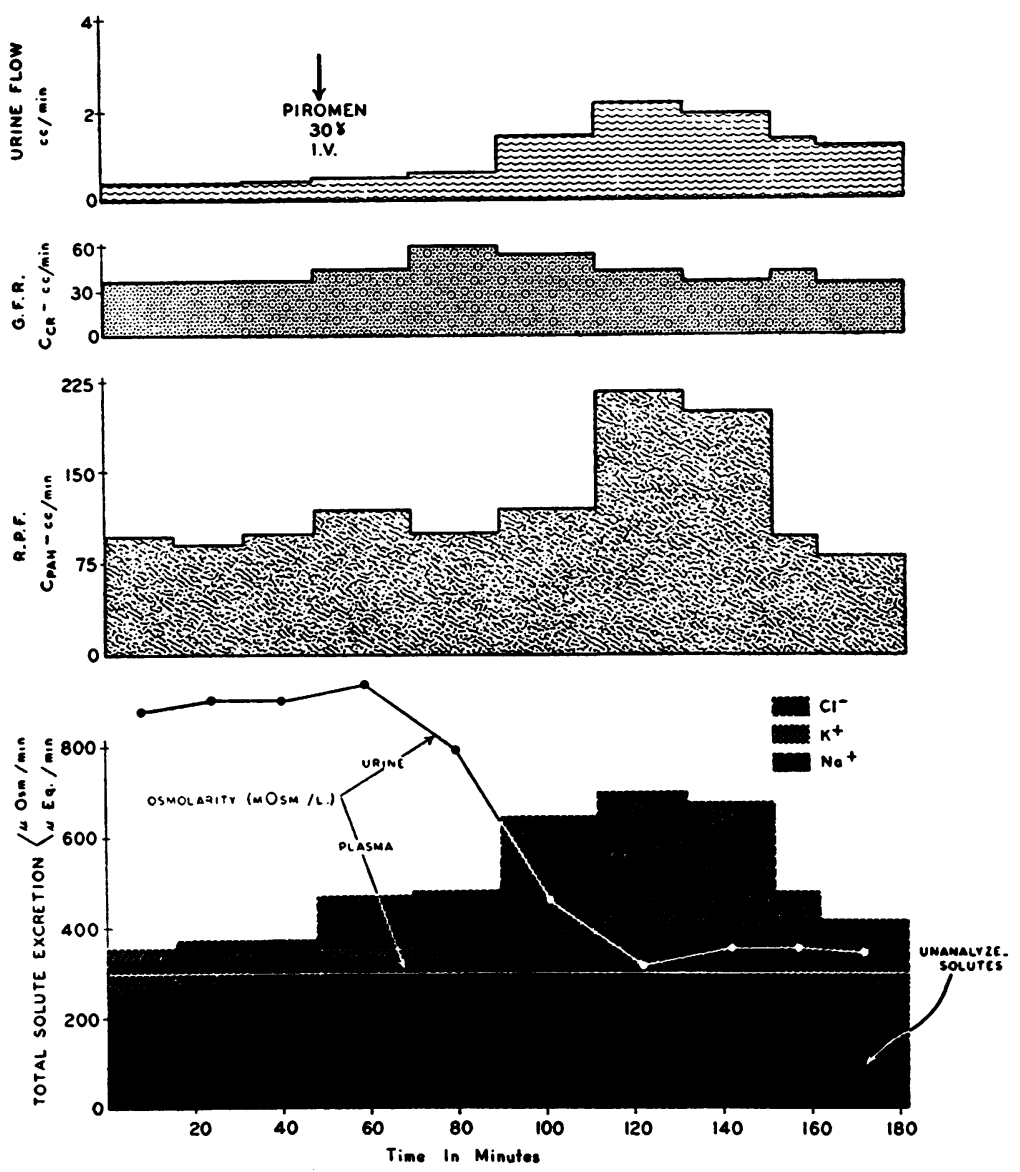

$006 " 917-0 . .12 \mathrm{Kg}$

Fig. 1A. The Effect of a Single Dose of Pyrogen on Renal HemodyNAMICS, SOlute EXCRETION AND URINARY OSMOLARITY

Note that the maximal change in filtration rate precedes the other changes.

pyrogen. These dogs were made hydropenic by withholding water for 18 to 20 hours. One animal received an increasing load of 25 per cent mannitol and then the pyrogen; when the "pyrogenic effect" became manifest, the infusion rate was slowed so as to decrease the rate of solute loading. In the other three dogs, a constant infusion (12 per cent sodium sulfate in one and 25 per cent mannitol in two) was maintained before and after the pyrogen administration. Plasma osmolarity was measured for each collection period in each of the four dogs.

\section{RESULTS}

\section{Group I Dogs-Table I (see also Figures 1a and} 1b)

The renal plasma flow rose to a maximum about 65 minutes, on the average, after the intravenous administration of pyrogen. This was followed in about 20 minutes by the maximal changes in urine flow, total solute, sodium chloride excretion and osmolar clearance. Twenty minutes later maximal changes in filtration rate, dilution of urine, and potassium excretion occurred.

1. Urine flow (Column 1). In all animals there was a rise in urine flow starting approximately 50 minutes after the injection of pyrogen, the increase varying from three to eleven times that of control flow with an average increase of sevenfold. In general, maximum urine flow was reached within $\mathbf{3 0}$ minutes of the gradual onset of diuresis ; it then decreased slightly and remained fairly constant during the rest of the study.

2. Glomerular filtration rate (Column 2). Of the six animals, three showed a slight increase ${ }^{6}$

6 Arbitrarily, a rise of 1 to $9 \mathrm{cc}$. was considered a slight increase, 10 to $19 \mathrm{cc}$ a moderate increase, and $20 \mathrm{cc}$. or more a marked increase in filtration rate. 
in filtration rate following pyrogen, one a moderate increase, and one a marked increase (see Figure 1a). One dog (No. 921) who received a continuous infusion of pyrogen in addition to an initial dose showed a slight decrease in filtration rate (Figure 1b). After reaching its peak change as a result of pyrogen administration, filtration rate usually returned to control levels within 45 minutes.

3. Renal plasma flow (Column 3). A uniform rise in renal plasma flow over control levels followed the intravenous injection of pyrogen. The average increase ranged from $49 \mathrm{cc}$. per minute (dog No. 915) to 224 cc. per minute (dog No. 925) which represent increases of 106 per cent and 125 per cent for these two dogs. The mean increase in flow for all dogs of this group was 98 per cent.

4. Osmolar clearance $\left(C_{\text {osm }}\right)$ (Column 4). In all dogs there was a rise in the osmolar clearance during the period of pyrogen activity. The aver- age osmolar clearance was 150 per cent above the control; the increases ranged between 0.6 (dog No. 955) and 2.3 (dog No. 921) cc. per minute.

5. Free water clearance $\left(C_{\mathrm{H}_{2} \mathrm{O}^{7}}\right)$ (Column 5). In four of the six dogs studied, free water clear-

\begin{abstract}
7 The terms positive and negative free water clearance ( + or $-\mathrm{C}_{\mathrm{H}_{2} \mathrm{O}}$ in Table $\mathrm{I}$ ) are used to describe the renal handling of the solute free water moiety in hydrated animals during the elaboration of a hypertonic (negative free water clearance) and a hypotonic (positive free water clearance) urine. The volume of free water is calculated from the formula, $\mathrm{V}=\mathrm{C}_{\mathrm{osm}}+\mathrm{C}_{\mathrm{H}_{2} \mathrm{O}}$, or $\mathrm{C}_{\mathrm{B}_{2} \mathrm{O}}=\mathrm{V}-$ Cosm. Conceptually, the term "negative free water clearance" means the amount of "distilled" water one would have to add to one minute's urine excretion to restore that urine to isotonicity (equal to plasma osmolarity); thus, this amount of water represents the per minute volume of "free water" removed by the tubules during the elaboration of hypertonic urine. The reverse is applicable to hypotonic urine, and represents the per minute volume of water one would have to "distill off" from a minute's excretion of urine in order to restore that urine to isotonicity.
\end{abstract}
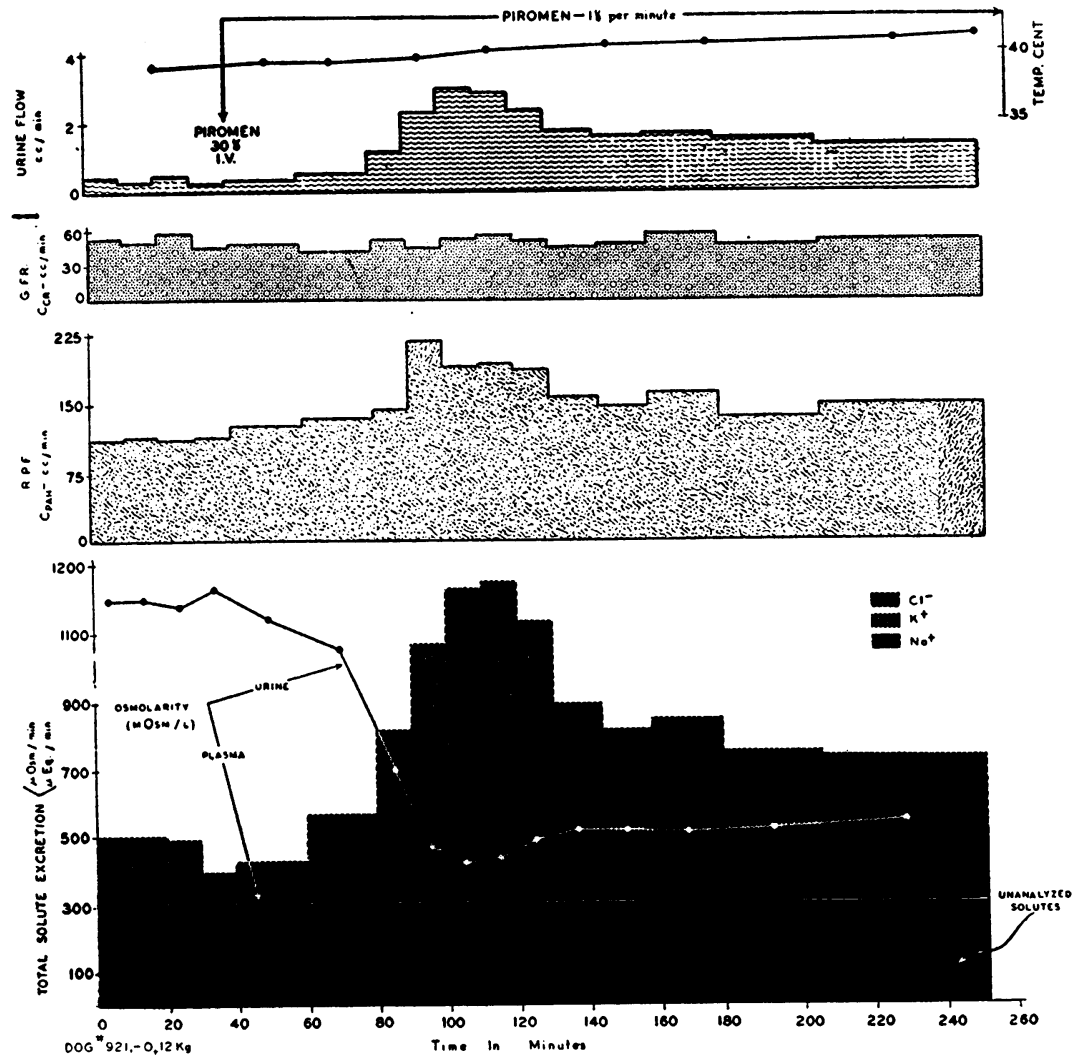

Fig. 1b. The Effect of a Single Dose Plus a Continuous Infusion of PyRogen on Renal Hemodynamics, Solute Excretion and URINARY Osmolarity Note that there is no significant change in filtration rate. 


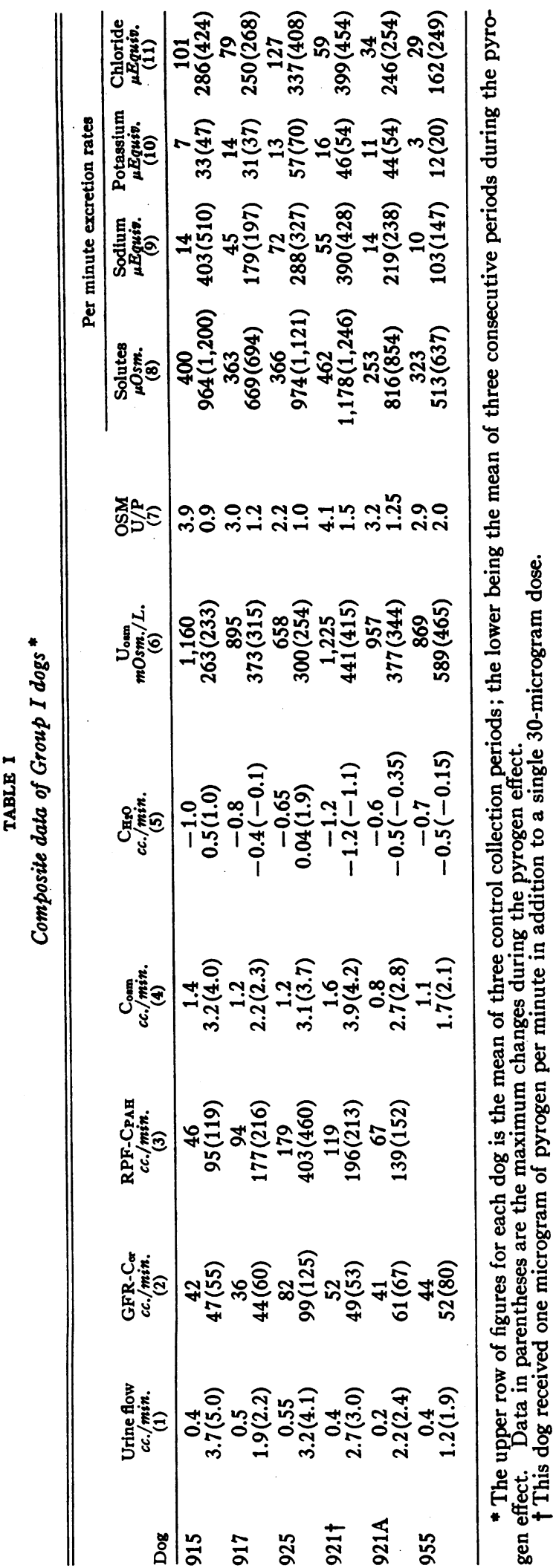

ance became less negative or even positive following the administration of pyrogen. In one dog (No. 921) the free water clearance remained unchanged.

6. Urine osmolarity (Column 6). In all dogs there was a fall in urine osmolarity, during the period of pyrogen activity, towards that of the plasma. The mean and standard deviation of the osmotic activity of dog plasma in this series is $310 \pm 14 \mathrm{mOsm}$. per L. From an average control level of 994 mOsm. per L. urine osmolarity fell to an average of $401 \mathrm{mOsm}$. per $\mathrm{L}$. at the height of pyrogen activity.

7. Osmotic $U / P$ ratio (Column 7 ). In all dogs there was a fall in the osmotic $U / P$ ratio toward 1.0. The highest control osmotic $U / P$ ratio was 4.1 which fell to 1.5 during pyrogen diuresis (dog No. 921). The smallest fall in osmotic $\mathrm{U} / \mathrm{P}$ ratio was seen in dog No. 955 (2.9 to 2.0).

8. Excretion of solutes.

A. Total solutes (Column 8). There was a uniform rise in total solute excretion for all dogs during the period of pyrogen activity as compared with the rates of solute excretion during the control period. The increase in solute excretion ranged between $190 \mu$ Osm. per minute (dog No. 955) and $716 \mu$ Osm. per minute (dog No. 921). Inspection of Table I and Figures $1 \mathrm{a}$ and $1 \mathrm{~b}$ show that the increased excretion of sodium, chloride, and potassium accounts in the main for the increase in total solute excretion, and there is no gross change in the excretion of other urinary solutes.

B. Sodium and chloride excretion (Columns 9 and 11). These two ions showed the most striking increase in excretion rate during pyrogen activity. The smallest change in the rate of sodium excretion was a tenfold increase from $10 \mu \mathrm{Eq}$. per minute to $103 \mu \mathrm{Eq}$. per minute (dog No. 955). The greatest change was a thirtyfold increase from $14 \mu \mathrm{Eq}$. to $403 \mu \mathrm{Eq}$. per minute at the height of the pyrogenic effect (dog No. 915). Chloride excretion on the other hand ranged from a threefold to a sevenfold increase in this group of animals.

C. Potassium excretion (Column 10). This ion showed a large increase in excretion rate during the pyrogenic effect, although it was not as marked as the effects on sodium and chloride. 
TABLE II

Effect of pyrogen on $T m_{0}$ and $T m_{P A H}$

\begin{tabular}{ccc}
\hline Dog No. & $\begin{array}{c}\text { Control } \\
\text { mgm./min. }\end{array}$ & $\begin{array}{c}\text { Pyrogen } \\
\text { diuresis } \\
m g m . / m i n .\end{array}$ \\
\hline \multicolumn{3}{c}{ A. TmPAB } \\
169 & 28.1 & \\
285 & 15.1 & 19.2 \\
182 & 12.5 & 17.0 \\
& B. TmG & 17.6 \\
169 & 207 & 208 \\
265 & 177 & 298 \\
115 & 127 & 142 \\
\hline
\end{tabular}

Potassium excretion increased fourfold except in dog No. 917 where only a twofold increase from $14 \mu \mathrm{Eq}$. per minute to $31 \mu \mathrm{Eq}$. per minute was noted.

Items 6 to $8 \mathrm{~A}-\mathrm{C}$ indicate that more solute and especially more electrolyte is excreted during the period when pyrogen acts on the kidney, at the same time that more free water is excreted.

\section{Group II dogs-Table II}

In the three dogs in whom the tubular maxima for PAH $\left(\mathrm{Tm}_{\mathrm{PAB}}\right)$ were studied during control periods and during a "pyrogenic effect," one showed a decrease, one remained essentially unchanged, and in the third there was a rise.

The same variability in response was noted in the three dogs in whom the tubular maxima for glucose $\left(\mathrm{Tm}_{\mathrm{G}}\right)$ were measured before and after the administration of a dose of pyrogen. One dog showed a fall following pyrogen, another a rise, and the third only a slight change.

\section{Group III dogs-Table III}

For the five animals in this group the lowest urine osmolarity during the initial water diuresis ranged between $66 \mathrm{mOsm}$. per L. and $145 \mathrm{mOsm}$. per L. and averaged 111 mOsm. per L. During the antidiuresis resulting from the Pitressin infusion, urine osmolarity rose to peaks ranging between 615 mOsm. per L. and 1400 mOsm. per L. and averaged 944 mOsm. per L. During the period of pyrogen activity, despite the continued Pitressin infusion, urine osmolarities fell to between $60 \mathrm{mOsm}$. per L. and 116 mOsm. per L., the average being $93 \mathrm{mOsm}$. per $\mathrm{L}$.

During the period of Pitressin antidiuresis osmolar clearances remained essentially unchanged (a mean of $1.5 \mathrm{cc}$. per minute from a mean of 1.6 cc. per minute during initial water loading). There was associated a marked and precipitous fall in free water clearance during Pitressin antidiuresis (a mean of minus $0.9 \mathrm{cc}$. per minute from a mean of plus $2.7 \mathrm{cc}$. per minute during the initial water loading). The antidiuretic effect was reflected in the fall in urine flow from $4.3 \mathrm{cc}$. per minute during water loading to $0.6 \mathrm{cc}$. per minute. With the onset of inhibition of the Pitressin ${ }^{\circledR}$ antidiuresis by pyrogen, osmolar clearances remained constant, but the free water clearance rose to a higher mean level (plus $3.4 \mathrm{cc}$. per minute) than was noted during the initial phase of water loading. Concomitantly, the mean urine flow reached higher levels (4.9 cc. per minute) than those attained during the same initial period.

\section{Group IV dogs-Table IV, Figure 2}

For the three dogs in whom the rate of solute loading was kept constant, urine flows averaged $3.9,4.8$, and $5.1 \mathrm{cc}$. per minute; total solute excretions averaged $2.46,2.75$, and $3.0 \mathrm{mOsm}$. per minute, respectively, during control periods. For the same periods osmolar clearance and $\mathrm{T}_{\mathrm{H}_{2} \mathrm{O}^{8}}^{\mathrm{C}}$

8 The symbol $\mathrm{T}_{\mathrm{H}_{2} \mathrm{O}}^{\mathrm{C}}$ (8) will be used to designate the removal of solute free water during a sustained concen-

TABLE III

The effect of pyrogen in water loaded dogs in which the water diuresis was inhibited by Pitressin (8)

\begin{tabular}{|c|c|c|c|c|c|c|c|c|c|c|c|c|}
\hline \multirow[b]{2}{*}{$\begin{array}{l}\text { Dog } \\
\text { No. }\end{array}$} & \multicolumn{4}{|c|}{ Initial water load } & \multicolumn{4}{|c|}{ Pitressin $\otimes$ effect } & \multicolumn{4}{|c|}{ Pyrogen effect } \\
\hline & $\begin{array}{c}\text { Min. } \\
\text {UUsm}_{\text {osm }} \\
\text { mOsm./L. }\end{array}$ & $\begin{array}{l}\text { Urine } \\
\text { flow } \\
\text { cc./min. }\end{array}$ & $\begin{array}{c}\mathrm{C}_{\text {omm }} \\
c c . / \min .\end{array}$ & $\underset{c c . / \min }{\mathrm{C}_{\mathrm{B}_{2} \mathrm{O}}}$ & $\begin{array}{c}\text { Max. } \\
\text { U.osm } \\
\text { mOsm./L. }\end{array}$ & $\begin{array}{l}\text { Urine } \\
\text { flow } \\
c c . / m i n \text {. }\end{array}$ & $\begin{array}{c}\text { Comm } \\
c c . / \min .\end{array}$ & $\begin{array}{c}\mathrm{C}_{\mathrm{B}_{2} \mathrm{O}} \\
c c . / \min \text {. }\end{array}$ & $\underset{\text { Min. }}{\text { UOsm./L. }}$ & $\begin{array}{l}\text { Urine } \\
\text { flow } \\
c c . / \min \text {. }\end{array}$ & $\begin{array}{c}\text { Cosm } \\
c c . / m i n .\end{array}$ & $\begin{array}{l}\mathrm{C}_{\mathrm{HzO}} \\
c c . / \min .\end{array}$ \\
\hline $\begin{array}{l}27 \\
53 \\
52 \\
82 \\
96\end{array}$ & $\begin{array}{r}100 \\
126 \\
120 \\
66 \\
145\end{array}$ & $\begin{array}{l}3.6 \\
4.0 \\
7.0 \\
4.7 \\
2.2\end{array}$ & $\begin{array}{l}1.2 \\
1.7 \\
2.8 \\
1.0 \\
1.1\end{array}$ & $\begin{array}{r}+2.4 \\
+2.3 \\
+4.2 \\
+3.7 \\
+1.1\end{array}$ & $\begin{array}{r}1,100 \\
835 \\
615 \\
770 \\
1,400\end{array}$ & $\begin{array}{l}0.3 \\
0.6 \\
1.5 \\
0.3 \\
0.2\end{array}$ & $\begin{array}{l}1.2 \\
1.6 \\
3.0 \\
0.7 \\
0.9\end{array}$ & $\begin{array}{l}-0.9 \\
-1.0 \\
-1.5 \\
-0.4 \\
-0.7\end{array}$ & $\begin{array}{r}104 \\
116 \\
107 \\
60 \\
79\end{array}$ & $\begin{array}{l}4.0 \\
4.4 \\
6.9 \\
6.5 \\
2.8\end{array}$ & $\begin{array}{l}1.4 \\
1.7 \\
2.5 \\
1.3 \\
0.7\end{array}$ & $\begin{array}{l}+2.6 \\
+2.7 \\
+4.4 \\
+5.2 \\
+2.1\end{array}$ \\
\hline Mean & 111 & 4.3 & 1.6 & +2.7 & 944 & 0.6 & 1.5 & -0.9 & 93 & 4.9 & 1.5 & +3.4 \\
\hline
\end{tabular}


TABLE IV

Data from hydropenic, solute-loaded dogs given pyrogen *

\begin{tabular}{|c|c|c|c|c|}
\hline $\begin{array}{l}\text { Urine } \\
\text { flow } \\
c c . / m i n .\end{array}$ & $\begin{array}{c}\text { Tot. } \\
\text { solute } \\
\text { excr.- } \\
\text { mOsm./min. }\end{array}$ & $\underset{c c . / \min .}{\mathrm{Cosm}_{\text {ond }}}$ & $\begin{array}{c}\mathrm{T}_{\mathrm{H} 2 O}^{\mathrm{C}} \\
c c . / \min .\end{array}$ & Period \\
\hline
\end{tabular}

Dog No. 414-Constant Infusion-25\% Mannitol

\begin{tabular}{lllll}
$\mathbf{5 . 0}$ & 2.91 & 8.8 & 3.8 & Control \\
$\mathbf{5 . 6}$ & 3.28 & 9.9 & 4.3 & Control \\
$\mathbf{4 . 8}$ & 2.84 & 8.6 & 3.8 & Control \\
$\mathbf{5 . 8}$ & 2.72 & 8.2 & 2.4 & Pyrogen effect \\
$\mathbf{6 . 3}$ & 2.74 & 8.2 & 1.9 & Pyrogen effect \\
$\mathbf{5 . 7}$ & 2.66 & 7.8 & 2.1 & Pyrogen effect \\
\hline
\end{tabular}

Dog No. 285-Constant Infusion-25\% Mannitol

\begin{tabular}{lllll}
\hline 3.9 & 2.46 & 7.4 & 3.5 & Control \\
4.0 & 2.48 & 7.4 & 3.4 & Control \\
3.9 & 2.45 & 7.3 & 3.4 & Control \\
5.0 & 2.15 & 6.4 & 1.4 & Pyrogen effect \\
5.3 & 2.22 & 6.6 & 1.3 & Pyrogen effect \\
5.3 & 2.28 & 6.7 & 1.4 & Pyrogen effect \\
\hline
\end{tabular}

Dog No. 416-Constant Infusion-12\% Sodium Sulfate

\begin{tabular}{lllll}
\hline 4.8 & 2.69 & 8.0 & 3.2 & Control \\
4.8 & 2.79 & 8.3 & 3.5 & Control \\
4.9 & 2.81 & 8.4 & 3.5 & Control \\
6.3 & 2.72 & 7.9 & 1.6 & Pyrogen effect \\
6.3 & 2.77 & 7.9 & 1.6 & Pyrogen effect \\
5.7 & 2.70 & 7.9 & 1.2 & Pyrogen effect
\end{tabular}

Dog No. 415-Changing Infusion Rate-25\% Mannitol

\begin{tabular}{rrrrl}
\hline 5.9 & 3.3 & 9.0 & 3.1 & Control \\
8.8 & 4.6 & 13.0 & 4.2 & Control \\
11.5 & 6.0 & 16.2 & 4.7 & Control \\
12.5 & 6.6 & 17.3 & 4.8 & Control \\
15.6 & 8.0 & 20.3 & 4.7 & Control \\
16.9 & 8.6 & 21.7 & 4.8 & Control \\
16.0 & 7.9 & 20.0 & 4.0 & Pyrogen effect \\
13.8 & 6.8 & 17.0 & 3.2 & Pyrogen effect \\
13.0 & 6.3 & 15.7 & 2.7 & Pyrogen effect \\
10.8 & 5.2 & 12.9 & 2.1 & Pyrogen effect \\
8.5 & 4.3 & 10.6 & 2.1 & Pyrogen effect \\
\hline
\end{tabular}

* See text for details.

averaged $7.35,8.20$, and $9.0 \mathrm{cc}$. per minute and $3.4,3.4$, and $4.0 \mathrm{cc}$. per minute, respectively.

During the "pyrogenic effect" urine flow rose in all animals, and there was a slight decrease in solute excretion. Associated with the rise in urine

trating stimulus (hydropenia plus solute loading). This symbol has the same significance as the "negative free water clearance" of Wesson and Anslow (9), and the "distal water economy" of Brodsky, Rapoport, and West (10). The symbol $\operatorname{Tm}_{\mathrm{H}_{2} \mathrm{O}}^{\mathrm{C}}$ (Figure 2) is meant to represent the constant maximum level of solute free water removed during the concentrating process at wide ranges of urine flow above a minimal level (e.g., dog No. 415, Control periods, Table IV). flow there was a fall in urine osmolarity and a decrease in $\mathrm{T}_{\mathrm{H}_{2} \mathrm{O}}^{\mathrm{C}}$.

Figure 2 is a plot of osmolar clearances against urine flows for an animal in whom the rate of infusion of solute was varied. It can be seen that during control periods, before the administration of pyrogen, the tubular removal of solute free water by the concentrating apparatus reaches a maximum $\left(\mathrm{Tm}_{\mathrm{H}_{2} \mathrm{O}}^{\mathrm{C}}\right)$ of $4.8 \mathrm{cc}$. per minute at urine flows above $9.0 \mathrm{cc}$. per minute (line A). During the "pyrogenic effect," this maximal rate of free water removal is decreased by more than half (line B).

\section{DISCUSSION}

The complex interrelationship between filtration rate and hormonal action on glomerular and tubular factors in determining the quality and quantity of elaborated urine is well known. No consistent relationship exists between renal plasma flow and the quality and quantity of excreted urine. The present studies have demonstrated that in response to intravenous pyrogen in proper doses normally hydrated anesthetized animals receiving a saline infusion develop a striking rise in solute excretion made up chiefly of sodium, potassium, and chloride. The consistent rise in solute excretion is usually, but not invariably, accompanied by a rise in filtration rate (see Figures $1 \mathrm{a}$ and $1 \mathrm{~b})$. The effects of a saline infusion on urine flow and solute excretion in dogs who do not receive pyrogen are minimal as compared to those receiving pyrogen over a similar period of time (11). Since there is no consistent alteration of proximal function $\left(\mathrm{Tm}_{\mathrm{G}}\right.$ measurements in dogs of Group II), the changes can scarcely be ascribed to tubular damage of a non-specific type. While physiological alterations of proximal tubular handling of solute and water may be induced by a large dose of pyrogen, and should not be ignored, their magnitude (if any) cannot be determined by ordinarily available methods. The exact mechanism of the increased electrolyte excretion seen during the pyrogenic effect is not clear. The excretion of electrolyte usually rises to a peak coincident with or shortly after the rise in filtration rate (see Figure 1b), declines slightly and is then maintained at a high level for many hours while the filtration rate returns to pre-pyrogen levels. This suggests a transient glomerular component 


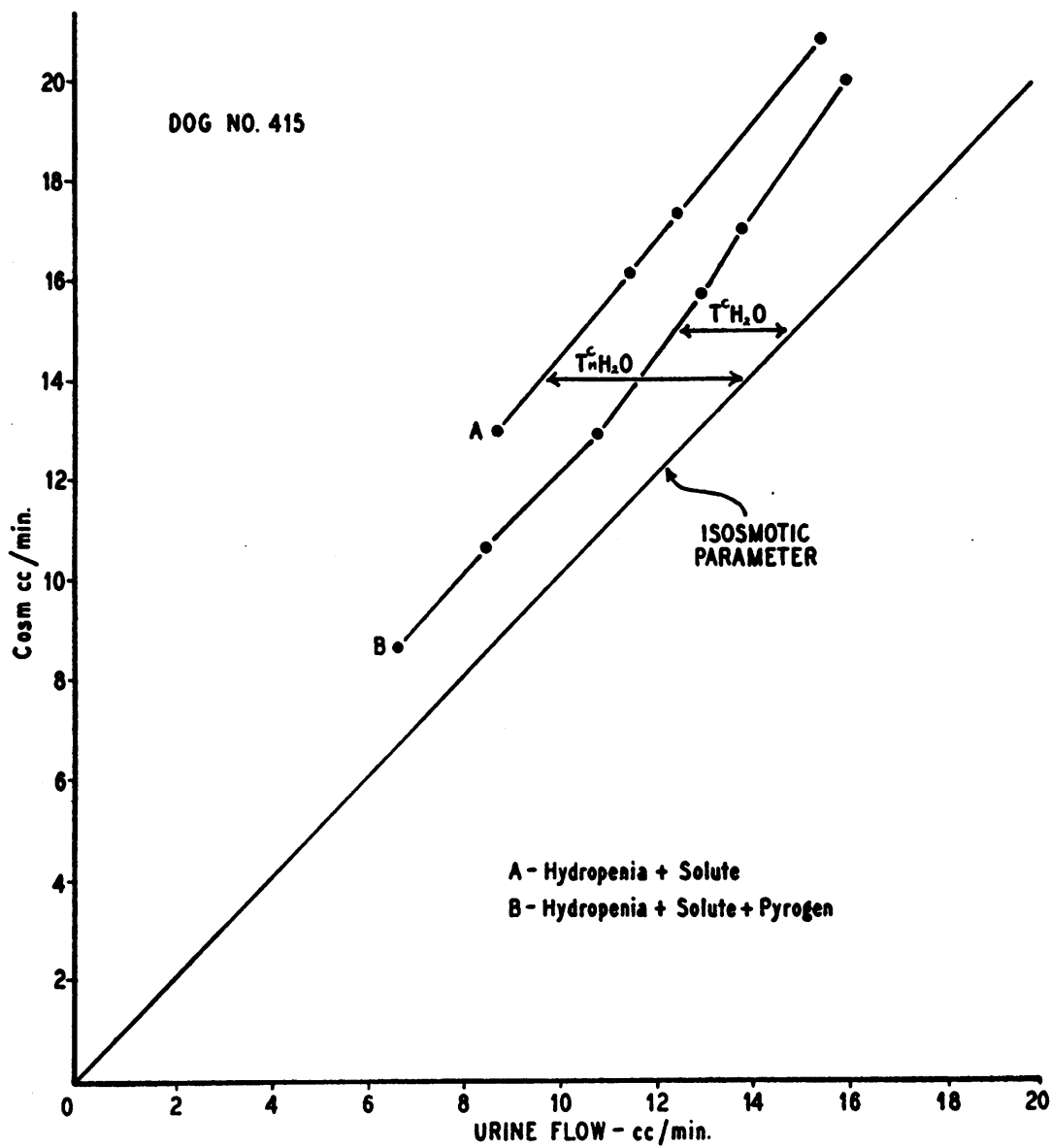

Fig. 2. A Plot of Urine Flow Against Coum in a Hydropenic Solute Loaded Dog Before and After Pyrogen

(increased filtered load) and a more prolonged tubular factor to account for the electrolyte excretion pattern during the pyrogenic effect. In dogs receiving a glucose and water infusion (Group III), electrolyte diuresis is less marked and transitory and follows the time course of changes in filtration rate.

Recent work has indicated that one of the effects of the administration of pyrogen is a diminution in adrenal hormone production (12). An altered adrenal "salt" steroid production induced during the pyrogenic reaction may not explain the increased urine electrolyte excretions completely, since a rise in excretion of solute, mainly electrolyte, is seen in adrenalectomized dogs given pyrogen (13). The possibility that pyrogens may produce their effects on electrolyte excretion through alterations in the paraventricular nuclei with a resulting natriuresis is not known at this time (14).
The uniform rise in total excreted solute following the administration of pyrogen does not in itself account for the uniform rise in minute flow of urine. It is apparent from Group I and Group III dogs that a dissociation between the renal handling of solute free water and solute water exists and that they may vary independently in response to pyrogens. The fall in osmotic $U / P$ ratio, the rise in free water clearance (negative towards positive) and the rise in osmolar clearance in normally hydrated dogs of Group I is supporting evidence. Furthermore, in animals of Group III during the inhibition of Pitressin by pyrogen urine flow increased without an increase in solute excretion. It is apparent from the Group III dogs that effective doses of pyrogen are capable of blocking fully antidiuretic doses of Pitressin ${ }^{\circ}$. Once established, even excessive doses of Pitressin ${ }^{\circ}$ will not alter the augmented urine flow of a py- 
rogen diuresis in water loaded animals. Thus, the effect of exogenous Pitressin ${ }^{\circledR}$ can be blocked by an effective dose of pyrogen.

Recent studies by del Greco and de Wardener (15), and Berliner and Davidson (16) have shown that under certain circumstances, in the absence of endogenous $\mathrm{ADH}$ of water loading, dogs may elaborate a concentrated urine ; further, these studies have implicated a fall in filtration rate and the rate at which solute is delivered to the concentrating apparatus, as possible factors. Recalculation of published data from solute loaded-hydropenic dogs in which "diabetes insipidus" was produced acutely by surgical means shows that such animals elaborate an isotonic urine at all rates of solute excretion (17); but under prolonged observation dogs made "diabetes insipidus" by surgical means may elaborate concentrated urine during hydropenia (18). Thus, at the two extremes of hydration the evidence indicates that posterior pituitary antidiuretic hormone is not the sole factor controlling the concentration of urine.

The biological similarity of exogenous $\mathrm{ADH}$ (Pitressin ${ }^{8}$ ) and endogenous posterior pituitary $\mathrm{ADH}$ in their ability to produce a concentrated urine under conditions of solute loading has been demonstrated (19). Two mechanisms may explain the interference with the maximum reabsorption of solute free water in hydropenic-solute loaded dogs by pyrogen (see Figure 2, line B) : 1. It can be assumed from the observations in Group III dogs that the concentrating effect of endogenous $\mathrm{ADH}$ has been eliminated by pyrogen in Group IV dogs. The horizontal distance between line $B$ and the isosmotic parameter, Figure 2, represents antidiuretic factors other than $\mathrm{ADH}$ which are not effected by pyrogen. 2. A decreased filtration rate and solute delivery to the concentrating segment is associated with increased free water reabsorption $(15,16)$. The corollary may follow that the increased filtration rate (and solute delivery) usually seen during the pyrogen effect evokes an opposite effect of decreased reabsorption of free water. Our evidence supports the first explanation since the requirement of increased solute excretion necessary for the second explanation was not found in our dogs (Group IV) at the time of the fall in free water reabsorption ("pyrogenic effect").

Evidence of increased salt excretion in humans during the infusion of pyrogenic inulin and triple typhoid (preceded by a transient fall with typhoid) is known $(20,21)$. The undesirable sideeffects of pyrogens (e.g., fever, abdominal cramps, etc.) in their present form limit their clinical usefulness when given in comparable doses to those described for the dog. Whether varying degrees of the phenomena reported here are common to all fever-producing agents and especially the endotoxins of gram negative bacteria is not known. Fever was not uniformly seen in the present studies; when present, its prevention by antipyretics, as in other studies with pyrogen, did not alter its renal effect (22). While no substance with the effects reported here has been described, the possibility that a polysaccharide (from gram negative bacteria) which might be clinically useful needs further investigation.

\section{SUMMARY AND CONCLUSIONS}

1. An increase in solute excretion and interference with the concentrating ability of the dogs' kidney has been demonstrated to be the result of the administration of a large dose of pyrogen.

2. Observations on the renal effects of pyrogen were made in 21 dogs, divided into four groupings. The following effects were noted: A. In dogs receiving a slow saline infusion, there was a uniform and often significant rise in urine flow, renal plasma flow, osmolar clearance and excretion of solute, mainly sodium, potassium and chloride. Inconsistent changes in filtration rate were noted as a result of pyrogen administration. There was also a uniform fall in osmotic $U / P$ ratio and a decrease in "negative free water" clearance. B. In six dogs tubular maxima for glucose and $\mathrm{PAH}$ were studied before and after pyrogen administration and found to give inconsistent and variable results. C. The administration of pyrogen to dogs in whom an initial water diuresis had been inhibited by Pitressin showed a resumption of the diuresis in spite of continued Pitressin ${ }^{\otimes}$ administration. This resumption of diuresis was not accompanied by an increased osmolar clearance, but rather by a dilute urine having a "positive free water" clearance. D. In hydropenic, solute-loaded dogs, $\operatorname{Tm}_{\mathrm{H}_{2} \mathrm{O}}^{\mathrm{C}}$ was reduced by about half.

3. The results, their interpretation and possible clinical application were discussed. 


\section{REFERENCES}

1. Brandt, J. L., Zumoff, B., Ruskin, H. D., and Castleman, L., Effect of large doses of pyrogen on water and solute excretion. Federation Proc., 1955, 14, 17.

2. Brandt, J. L., Ruskin, H. D., Zumoff, B., Castleman, L., and Zuckerman, S., Inhibition of renal tubular responsiveness to antidiuretic hormone by pyrogens. Proc. Soc. Exper. Biol. \& Med., 1955, 88, 451.

3. Bonsnes, R. W., and Taussky, H. H., On the colorimetric determination of creatinine by the Jaffe reaction. J. Biol. Chem., 1945, 158, 581.

4. Smith, H. W., Finkelstein, N., Aliminosa, L., Crawford, B., and Graber, M., The renal clearances of substituted hippuric acid derivatives and other aromatic acids in dog and man. J. Clin. Invest., 1945, 24, 388.

5. Nelson, N., A photometric adaptation of the Somogyi method for the determination of glucose. J. Biol. Chem., 1944, 153, 375.

6. Schales, O., and Schales, S. S., A simple and accurate method for the determination of chloride in biological fluids. J. Biol. Chem., 1941, 140, 879.

7. Goldring, W., and Chasis, H., Hypertension and $\mathrm{Hy}-$ pertensive Disease, New York, The Commonwealth Fund, 1944.

8. Zak, G. A., Brun, C., and Smith, H. W., The mechanism of formation of osmotically concentrated urine during the antidiuretic state. J. Clin. Invest., 1954, 33, 1064.

9. Wesson, L. G., Jr., and Anslow, W. P., Jr., Effect of osmotic and mercurial diuresis on simultaneous water diuresis. Am. J. Physiol., 1952, 170, 255.

10. Brodsky, W. A., Rapoport, S., and West, C. D., The mechanism of glycosuric diuresis in diabetic man. J. Clin. Invest., 1950, 29, 1021.
11. Murray, J. F., Jones, A., and Brandt, J. L., Studies of the effects of large doses of bacterial pyrogen in the dog: II The effect of varying states of hydration and concentration of infused solutes. To be published.

12. Rosenfeld, G., In vitro influence of bacterial pyrogens on adrenocortical function of perfused calf adrenals. Am. J. Physiol., 1955, 182, 57.

13. Brandt, J. L., et al., Unpublished observations.

14. Keeler, R. J., Sodium excretion in the rat after hypothalamic lesions and renal denervation. J. Physiol., 1955, 130, 9P.

15. del Greco, F., and de Wardener, H. E., The effect on urine osmolarity of a transient reduction in glomerular filtration rate and solute output during a "water" diuresis. J. Physiol., 1956, 131, 307.

16. Berliner, R. W., and Davidson, D. G., Production of hypertonic urine in the absence of pituitary antidiuretic hormone. J. Clin. Invest., 1956, 35, 690.

17. Brodsky, W. A., Austing, M. E., Moxley, T. L., and Grubbs, T. A., Composition of excreted solutes in experimental diabetes insipidus. Mechanism of urinary dilution. Am. J. Physiol., 1953, 174, 448.

18. Levkoff, A. H., Demunbrun, T. W., and Keller, A. D., Disparity between fluid intake and renal concentrating deficit in dogs with diabetes insipidus. Polydipsia, independent of the renal concentrating deficit. Am. J. Physiol., 1954, 176, 25.

19. West, C. D., Traeger, J., and Kaplan, S. A., A comparison of the relative effectiveness of hydropenia and of Pitressin in producing a concentrated urine. J. Clin. Invest., 1955, 34, 887.

20. Newman, E. V., Personal communication.

21. Lathem, W., Urinary excretion of sodium and potassium during the pyrogenic reaction. J. Clin. Invest., 1954, 33, 951.

22. Smith, H. W., Physiology of the renal circulation. Harvey Lect., 1939-1940, 35. 166.

\section{SPECIAL NOTICE TO SUBSCRIBERS}

Post Offices will no longer forward the Journal when you move.

Please notify The Journal of Clinical Investigation, Business Office, 622 West 168th Street, New York 32, N. Y. at once when you have a change of address, and do not omit the zone number if there is one. 